\title{
RANCANG BANGUN SISTEM MONITORING PENGUKUR CUACA MENGGUNAKAN MINIMUM SYSTEM ARDUINO
}

\author{
Khoirul Fatihin 1 , Joseph Dedy Irawan ${ }^{2}$, Renaldi Primaswara. P. ${ }^{3}$ \\ Program Studi Teknik Informatika S1, Fakultas Teknologi Industri \\ Institut Teknologi Nasional Malang, Jalan Raya Karanglo km 2 Malang, Indonesia \\ fatikhin23@gmail.com
}

\begin{abstract}
ABSTRAK
Pengamatan unsur cuaca sangat diperlukan oleh manusia. hampir semua kalangan membutuhkanya, mulai dari instansi pemerintah, swasta, perorangan, bahkan pelajar dan mahasiswa terkadang juga membutuhkan datadata cuaca tersebut. Namun BMKG selaku penyedia data cuaca di indonesia tidak bisa memberikan data cuaca tersebut ke sembarang orang, terlebih lagi data mentah.

Dengan perkembangan teknologi sekarang dan memanfaatkan IoT kita bisa membuat alat pengukuran cuaca dan data logger sendiri. data ini nantinya juga bisa bermanfaat dan diakses oleh semua orang. dengan memanfaatkan minimum sistem/mikroontroler dan beberapa sensor-sensor, alatnya pun juga akan lebih praktis(portable) dan lebih murah. namun pastinya alat ini juga memiliki kekurangan seperti nilai keakuratannya yang sedikit kurang jika dibanding dengan alat ukur yang sudah ada

Sistem dan alat dapat bekerja dengan cukup baik, hal ini ditunjukkan dengan semua sensor mampu menangkap besaran fisik disekitarnya dan menampilkanya pada website monitoring. Meskipun tidak seakurat alat yang sudah ada dan memiliki nilai error.
\end{abstract}

\section{Kata kunci : Pengukur Cuaca, IoT, Stasiun Cuaca, Sensor Cuaca, Website}

\section{PENDAHULUAN}

Pengamatan unsur cuaca sangat diperlukan untuk kesejahteraan dan keperluan manusia. Unsur cuaca yang diamati akan dijadikan bahan untuk memprakirakan cuaca pada waktu yang akan datang. Data unsur cuaca ini sangat berguna untuk mengetahui klimatologis suatu daerah, sehingga manusia dapat memanfaatkan kondisi cuaca tersebut sesuai kebutuhan masing-masing pihak. Data cuaca juga bisa dimanfaatkan untuk mengurangi atau bahkan menghindari resiko akibat buruknya cuaca tersebut. selain itu data tersebut juga diperlukan untuk penelitian ataupun pembelajaran, misalnya data mining. Dengan menggunakan salah satu metode pada data mining maka akan bisa dicari pola dan prediksi cuaca.

Badan Meteorologi Klimatologi dan Geofisika (BMKG) merupakan instansi pemerintah yang ditugaskan untuk mengamati cuaca dan memberikan prakiraan cuaca serta peringatan dini yang berhubungan dengan cuaca. Dalam proses pengamatan cuaca diperlukan instrument yang akan ditempatkan dalam suatu lokasi tertentu untuk mewakili kondisi lingkungan daerah sekitarnya yang disebut sebagai stasiun cuaca [1].

Namun tidak setiap daerah terjangkau oleh BMKG. Untuk mendapatkan data tersebut juga harus melewati mekanisme-mekanisme tertentu. Pada website BMKG sendiri data yang ditampilkan juga terbatas. Tidak semua orang bisa mengaksesnya. Untuk peneliti yang membutuhkan data ini pasti kesulitan jika di sekitar daerahnya tidak terdapat stasiun cuaca.

Dari uraian permasalahan di atas, tercipta sebuah pemikiran untuk membuat stasiun cuaca mini yang murah dan praktis. Penulis mengambil judul rancang bangun sistem monitoring pengukur cuaca menggunakan arduino. Sistem ini nantinya mampu menyediakan data-data pengukuran cuaca dalam interval waktu tertentu dan terdapat beberapa parameter yang bisa digunakan untuk memprediksi cuaca.

\section{TINJAUAN PUSTAKA \\ 2.1 Penelitian Terdahulu}

Salindri Z. H. dkk dengan penelitiannya yang berjudul "Rancang Bangun Mini Weather Station Menggunakan Web Berbasis Arduino Atmega 2560", telah berhasil membuat Mini Weather Station (MWS) yang dapat diakses melalui website, sehingga pengguna dapat mengetahui perubahan cuaca di suatu daerah tanpa perlu datang ke daerah tersebut. Perancangan MWS ini menggunakan mikrokontroler Arduino ATMega 2560. Parameter cuaca yang diukur pada MWS meliputi suhu dan kelembaban udara menggunakan sensor SHT11, kadar gas $\mathrm{CO} 2$ menggunakan sensor MQ135, kadar gas CO menggunakan sensor MQ7, tekanan udara menggunakan sensor BMP180, serta curah hujan menggunakan tipping bucket. Hasil pengukuran kelima buah sensor tersebut ditampilkan melalui sebuah LCD 4×20 dan website dengan menggunakan modul GSM SIM900. [2].

Thoyibi M. Masyud. Dkk (2018) dengan penelitiannya yang berjudul "Rancang Bangun Sistem Pengukur Cuaca Otomatis Menggunakan Arduino Dan Terintegrasi Dengan Website", Penelitian ini dilatarbelakangi oleh jumlah curah hujan hingga saat ini masih banyak dilakukan secara manual dimana kesalahan akibat faktor manusia (human error) sering 
terjadi, sementara bila dilakukan secara terus menerus akan mengakibatkan ketidakseimbangan lingkungan. Maka dibuatlah Mini Weather Station (MWS) dengan ukuran yang kecil (portable) serta konsumsi daya yang rendah. Hasil penelitian ini telah berhasil membuat suatu prototype yang selanjutnya dapat dikembangkan untuk keperluan kehidupan sehari hari dalam menjalankan aktifitas untuk memantau perubahan cuaca yang tidak menentu meskipun dalam jarak jauh. [3].

Menurut penelitian yang dilakukan oleh Irawan, J. D. dkk (2016), Diharapkan dengan dibuatnya alat kuci elektronik menggunakan RFID nantinya dapat membantu proses pencatatan secara elektronik bagi siapa saja yang masuk ke dalam rumah, sehingga jika ada tamu yang tak diundang dapat diketahui siapa dan kapan mereka memasuki rumah atau gedung, serta dengan teknologi internet yang sudah semakin maju maka dengan memanfaatkan jaringan internet data elektronik tersebut dapat dipantau dari mana saja dengan menerapkan sistem intenet of things (IoT. [4].

Riski Fitriani (2019) dengan penelitianya yang berjudul "Prototipe Pengukur Cuaca Menggunakan Arduino" telah berhasil membuat membuat prototipe pengukur cuaca yang dapat memberikan informasi cuaca secara real time, murah, simple dan efisien. Prototipe yang dibuat menggunakan Arduino mega, dengan beberapa sensor pembaca cuaca seperti: sensor curah hujan, sensor suhu dan kelembapan udara, sensor arah angin, sensor kecepatan angin dan sensor tekanan absolut. Data sensor tersebut dikirim ke data center berbasis Wireless Sensor Network (WSN) menggunakan komunikasi Radio Frequency (RF) yaitu Xbee Pro S3B 900 MHz, sehingga tidak perlu mengeluarkan biaya dalam proses pengiriman data.[5]

\subsection{Landasan Teori}

\subsubsection{Arduino Uno}

Arduino Uno adalah board mikrokontroler berbasis ATmega328 (datasheet). Memiliki 14 pin input dari output digital dimana 6 pin input tersebut dapat digunakan sebagai output PWM dan 6 pin input analog, $16 \mathrm{MHz}$ osilator kristal, koneksi USB, jack power, ICSP header, dan tombol reset. Untuk mendukung mikrokontroler agar dapat digunakan, cukup hanya menghubungkan Board Arduino Uno ke komputer dengan menggunakan kabel USB atau listrik dengan AC yang-ke adaptor-DC atau baterai untuk menjalankannya.

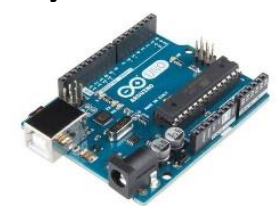

Gambar 1 Arduino Uno

\subsubsection{Sensor DHT 11}

DHT11 adalah salah satu sensor yang dapat mengukur dua parameter lingkungan sekaligus, yakni suhu dan kelembaban udara (humidity). Dalam sensor ini terdapat sebuah thermistor tipe NTC (Negative Temperature Coefficient) untuk mengukur suhu, sebuah sensor kelembaban tipe resisitif dan sebuah mikrokontroller 8-bit yang mengolah kedua sensor tersebut dan mengirim hasilnya ke pin output dengan format single-wire bi-directional (kabel tunggal 2 arah).

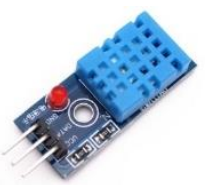

Gambar 2 Sensor DHT 11

\subsubsection{Sensor BMP 180}

Bmp180 adalah sensor tekanan barometrik (digital barometric pressure sensor) dari Bosch Sensortec yang berkinerja sangat tinggi yang dapat diaplikasikan pada berbagai perangkat bergerak seperti smartphone, komputer tablet, dan peralatan olah raga portabel. Sensor ini bekerja dengan menghubungkan antara mikro dengan sensor adalah melalui jalur SCL dan SDA pada kedua komponen. Prinsip kerja sensor BMP180 (khususnya dalam mengukur tekanan udara) akan mendeteksi ketinggian suatu obyek dengan memanfaatkan tekanan udara ketika sensor berada di ketinggian pada suatu tempat atau wilayah.

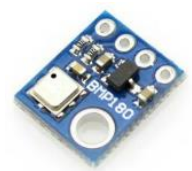

Gambar 3 Sensor BMP 180

\subsubsection{Sensor Hujan}

Sensor hujan adalah jenis sensor yang berfungsi untuk mendeteksi terjadinya hujan atau tidak, yang dapat difungsikan dalam segala macam aplikasi dalam kehidupan sehari - hari. Prinsip kerja dari module sensor ini yaitu pada saat ada air hujan turun dan mengenai panel sensor maka akan terjadi proses elektrolisasi oleh air hujan. Dan karena air hujan termasuk dalam golongan cairan elektrolit yang dimana cairan tersebut akan menghantarkan arus listrik.

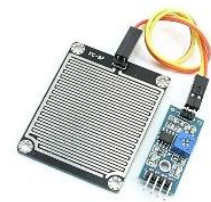

Gambar 4 Sensor Hujan

\subsubsection{Sensor Anemometer}

Anemometer merupakan sensor angin untuk mengukur kecepatan angin di sekitaran-nya dan juga banyak digunakan pada stasiun pengukuran cuaca. 
Pengukuran kecepatan/RPM angin yang bisa digunakan ada beberapa metode yang digunakan, salah satunya menghitung waktu yang terjadi tiap munculnya sinyal pulsa

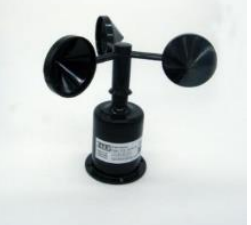

Gambar 5 Sensor Anemometer

\subsubsection{Modul ESP8266}

ESP8266 adalah sebuah modul WiFi yang akhirakhir ini semakin digemari para hardware developer. Selain karena harganya yang sangat terjangkau, modul WiFi serbaguna ini sudah bersifat SoC (System on Chip), sehingga kita bisa melakukan programming langsung ke ESP8266 tanpa memerlukan mikrokontroller tambahan. Kelebihan lainnya, ESP8266 ini dapat menjalankan peran sebagai adhoc akses poin maupun klien sekaligus.

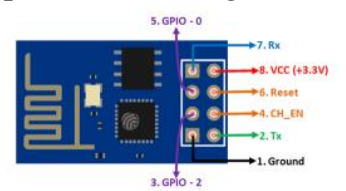

Gambar 6 Modul ESP 8266

\subsubsection{Modul gps Neo-6m}

Seri modul NEO-6 adalah keluarga penerima GPS yang berdiri sendiri yang menampilkan mesin pemosisian u-blox 6 kinerja tinggi. Penerima fleksibel dan hemat biaya ini menawarkan banyak pilihan konektivitas dalam paket miniatur 16 x 12.2 x 2.4 $\mathrm{mm}$. Arsitekturnya yang ringkas dan opsi daya dan memori menjadikan modul NEO-6 ideal untuk perangkat seluler yang dioperasikan dengan baterai dengan batasan biaya dan ruang yang sangat ketat.

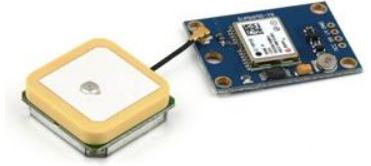

Gambar 7 Modul GPS Neo-6m

\subsubsection{Iklim dan Cuaca}

Cuaca adalah kondisi udara yang terjadi di suatu daerah atau wilayah dalam periode waktu tertentu. Cuaca hanya terjadi dalam waktu singkat yaitu hanya beberapa jam yang disebabkan oleh adanya perbedaan suhu dan kelembaban (tingkat kebasahan udara). Sedangkan iklim adalah kondisi rata-rata cuaca pada suatu wilayah yang sangat luas dalam periode waktu yang sangat lama. Iklim terjadi dalam waktu lama, umumnya 11-30 tahun yang disebabkan oleh letak geografis dan topografi suatu wilayah yang mempengaruhi posisi matahari terhadap daerah di bumi.

\section{METODE PENELITIAN}

\subsection{Perancangan Hardware}

Sistem pengukur cuaca / mini weather station adalah sebuah alat yang digunakan untuk mengukur cuaca secara portable dengan website sebagai media pelaporan. Sistem ini juga menjadi salah satu solusi bagi yang membutuhkan data pengukuran cuaca untuk digunakan sebagai penelitian/pembelajaran, karena mekanisme yang tidak mudah untuk mendapatkan data pengukuran cuaca dari instansi terkait. Beberapa hardware yang dibutuhkan dalam pembuatan sistem ini adalah Arduino uno, Sensor BMP 180, Sensor Anemometer, Sensor Hujan, Sensor Suhu dan Kelembaban, Modul GPS Neo-6m, Modul ESP8266-01, Kabel jumper, dan Breadboard. Berikut penjelasan mengenai perancangan hardware dari sistem pengukur cucaca.

\subsubsection{Blok Diagram Sistem}

Blok diagram adalah diagram dari sebuah sistem, di mana bagian utama atau fungsi yang diwakili oleh blok dihubungkan dengan garis, yang menunjukkan hubungan dari blok. . Berikut ini diagram blok dari sistem pengukur cuaca :

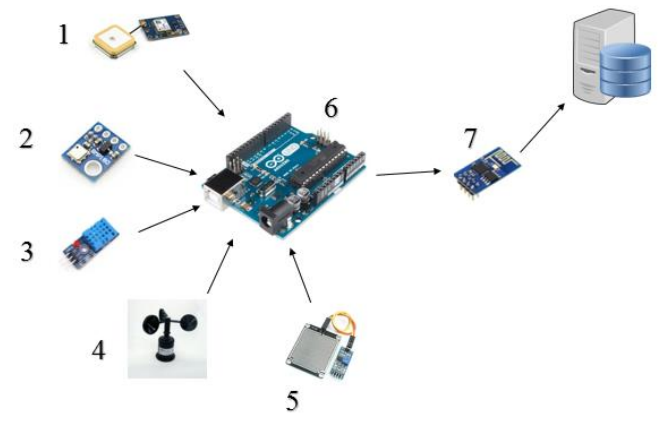

Gambar 8 Blok Dagram sistem

Adapun penjelasan dari diagram blok pada gambar 8 Adalah sebagai berikut:

1. Modul GPS Neo-6m berfungsi menagkap koordinat lokasi berupa longitude dan latitude

2. Sensor BMP 180 berfungsi sebagai pendeteksi ketinggian dan tekanan udara

3. Sensor DHT 11 berfungsi sebagai pendeteksi suhu dan kelembaban

4. Sensor Anemometer berfungsi sebagai pendeteksi kecepatan angina

5. Sensor Hujan berfungsi sebagai pendeteksi ada tau tidaknya hujan

6. Arduino uno berfungsi sebagai pengendali semusa komponen-komponen yang terhubung dengan perangkat tersebut serta menangkap hasil dari besaran fisik yang dibaca sensor dan kemudian dikalibrasi serta dihitung sehingga menjadi sebuah informasi.

7. Modul ESP 8266 berfungsi sebagai media penghubung antara arduino dan internet 


\subsubsection{Skema Rancangan dan Alokasi Pin}

Alokasi pin adalah penempatan pin-pin yang terhubung satu sama lain pada minimum sistem Arduino Uno. Berikut alokasi pin dari semua sensor dan minimum sistem arduino

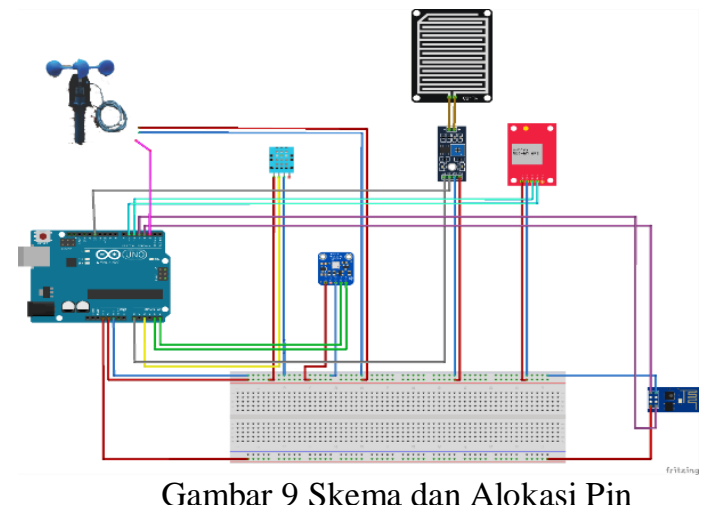

\subsection{Perancangan Software}

Pada perancangan ini berisi mengenai software dan cara kerja system Pengukur Cuaca. Adapun beberapa software yang digunakan yaitu Arduino IDE, XAMPP, Sublime Text 3, dan Web Browser.

\subsubsection{Struktur Menu Website}

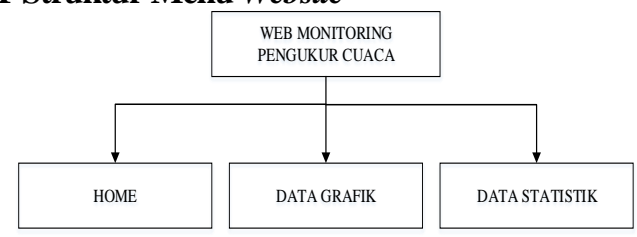

Gambar 10 Struktur Menu Website

Menu Home : merupakan menu utama berisi tampilan data cuaca terbaru beserta lokasi dan waktu

Data Grafik : berisi tampilan data cuaca terbaru dalam bentuk grafik

Data Statistik : berisi tampilan data cuaca terbaru dalam bentuk statistic atau tabel, terdapat filter tanggal untuk menampilkan dan men-download data

Pada flowchart di atas menjelaskan tentang alur sistem hardware. system dimulai dengan inisiai sensor dan variable serta normalisasi GPS, sonsor GPS akan membaca lokasi dimana sistem berada, kemudian dilanjutkan dengan semua sensor (suhu dan kelembaban, tekanan udara, kecepatan angin, serta deteksi hujan) akan membaca nilai besara fisik diseitarnya. Data hasil dari pembacaan sensor akan ditampilkan pada serial monitor. Setelah itu konfigurasi Wifi untuk pengiriman data (connecting). Untuk proses pengiriman data jika gagal maka sistem akan kembali membaca lokasi (sensor GPS) dan jika berhasil maka data akan disimpan pada database yang kemudian ditampilkan pada web monitoring.

\subsubsection{Flowchart sistem Hardware}

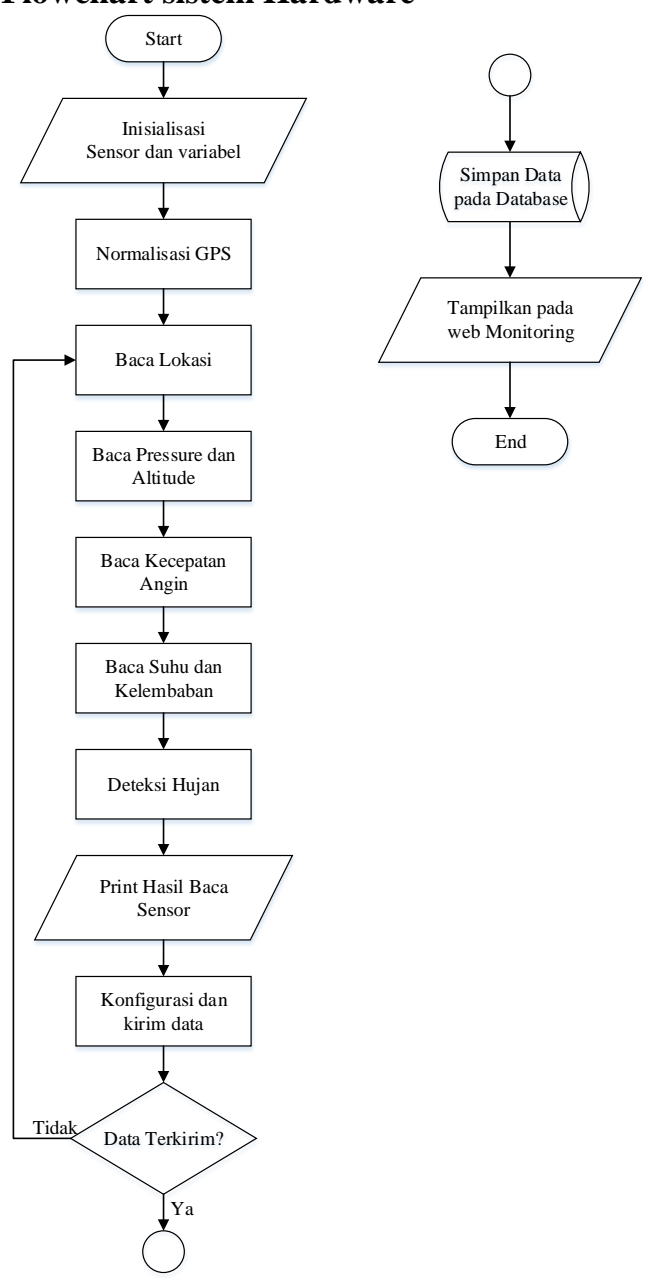

Gambar 11 Flowchart Sistem Hardware

\subsubsection{Flowchart Sfotware (Website)}

Pada gambar 12 Pada alur program tersebut website akan melakukan request atau membaca database. Data terbaru akan ditampilkan satu persatu pada halaman dashboard. Pada halaman grafik data terbaru akan ditampilkan dalam bentuk grafik. Kemudian pada halaman statitik semua data terbaru akan ditampilkan dalam bentuk tabel, pada halaman ini terdapat inputan filter berupa datetimpicker, user dapat menset sesuai tanggal yang kemudian bisa 
memilih menampilkannya saja atau mengunduh data tersebut.

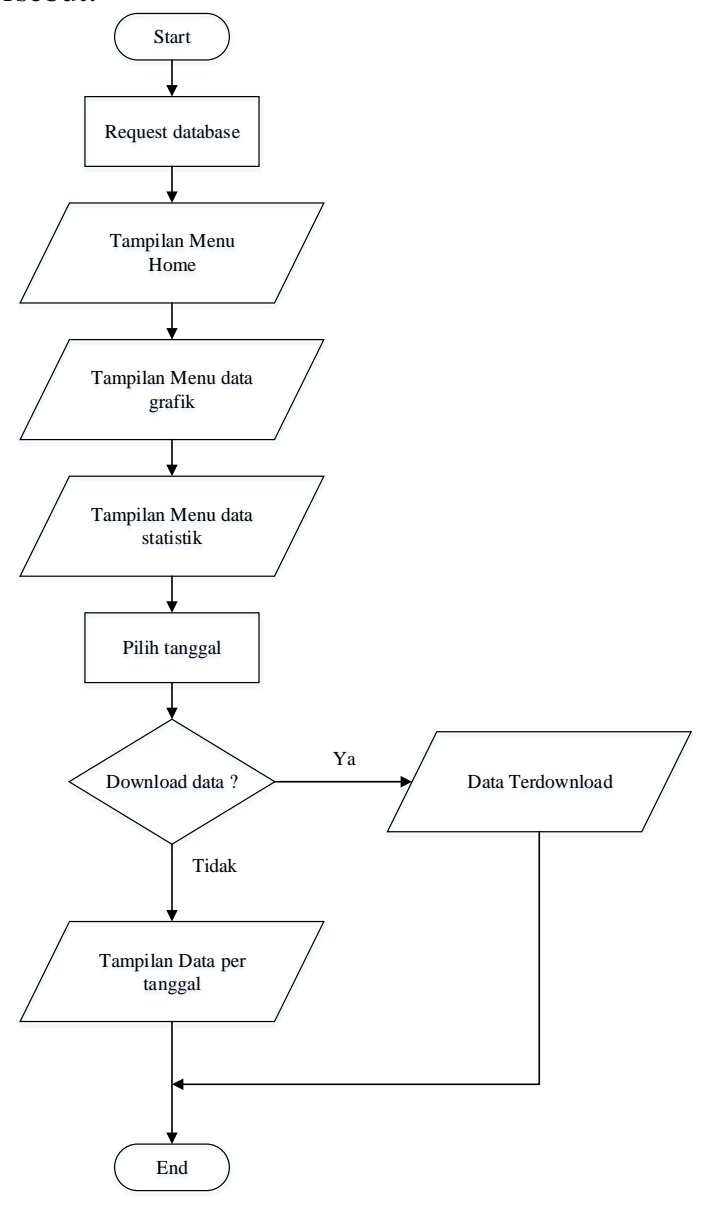

Gambar 12 Flowchart Software

\section{HASIL DAN PEMBAHASAN}

\subsection{Tampilan Rangkaian Alat}

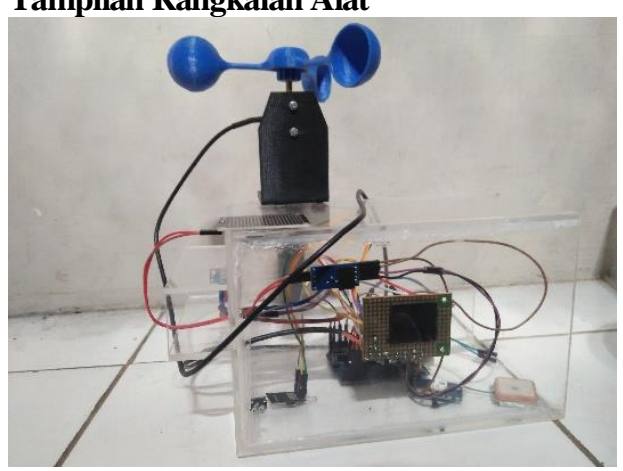

Gambar 13 Tampilan Rangkaian Alat

Pada gambar 4.1 merupakan model dari desain hardware yang dibentuk dari beberapa komponen atau sensor dengan fungsinya masing-masing. Alat dibuat dan dikemas secara tertutup dimakasudkan untuk menghindari gangguan dari luar seperti air.

\subsection{Pengujian Alat}

\subsubsection{Pengujian Modul GPS Neo-6m}

Pengujian menggunakan modul GPS Neo-6m berfungsi untuk mengetahui tingkat keakuratan dalam pembacaan lokasi. Hasil dari pengujian modul GPS ini akan dibandingkan dengan hasil pembacaan lokasi menggunakan Smartphone Oppo A37. Berikut hasil pengujian Modul GPS Neo-6m

Tabel 1 Pengujian Modul GPS

\begin{tabular}{|c|c|c|c|c|c|c|c|}
\hline \multirow{2}{*}{ No } & \multicolumn{2}{|c|}{ Modul GPS } & \multicolumn{2}{|c|}{ Smartphone } & \multirow{2}{*}{$\begin{array}{c}\mathbf{A} \\
(\mathbf{m})\end{array}$} & \multirow{2}{*}{$\begin{array}{c}\text { B } \\
(\mathbf{m})\end{array}$} & \multirow{2}{*}{$\begin{array}{c}\text { C } \\
(\mathbf{m})\end{array}$} \\
\hline & Lat & Long & Lat & Long & & & \\
\hline 1 & $\begin{array}{c}- \\
7.910781\end{array}$ & $\begin{array}{c}112.63 \\
7016\end{array}$ & $\begin{array}{c}7.910 \\
783\end{array}$ & $\begin{array}{c}112.63 \\
6999\end{array}$ & 2 & 1,90 & 0,1 \\
\hline 2 & $\begin{array}{c}- \\
7.910781\end{array}$ & $\begin{array}{c}112.63 \\
7016\end{array}$ & $\begin{array}{c}- \\
7.910 \\
783\end{array}$ & $\begin{array}{c}112.63 \\
6999\end{array}$ & 2 & 1,90 & 0,1 \\
\hline 3 & $\begin{array}{c}- \\
7.910792\end{array}$ & $\begin{array}{c}112.63 \\
6993\end{array}$ & $\begin{array}{c}- \\
7.910 \\
783\end{array}$ & $\begin{array}{c}112.63 \\
6999\end{array}$ & 0 & 1,20 & 1,2 \\
\hline 4 & $\begin{array}{c}- \\
7.910792\end{array}$ & $\begin{array}{c}112.63 \\
6993\end{array}$ & $\begin{array}{c}- \\
7.910 \\
783\end{array}$ & $\begin{array}{c}112.63 \\
6999\end{array}$ & 0 & 1,20 & 1,2 \\
\hline 5 & $\begin{array}{c}- \\
7.910814\end{array}$ & $\begin{array}{c}112.63 \\
7039\end{array}$ & $\begin{array}{c}- \\
7.910 \\
783\end{array}$ & $\begin{array}{c}112.63 \\
6999\end{array}$ & 5 & 5,63 & 0,6 \\
\hline \multicolumn{7}{|c|}{ Rata-Rata } & 0,5 \\
\hline
\end{tabular}

Menghitung Nilai Eucluidian

$B=\left(\sqrt{(x 1-x 2)^{2}+(y 1-y 2)^{2}}\right) * 111.319$

Keterangan :

A : Tracking menggunakan Google map

B : Perhitungan Euclidian

C : Selisi A dan B

$111,319 \mathrm{~km}$ : nilai $1^{\circ}$ (derajat) bumi

Pada 5 kali percobaan pengujian modul GPS menghasilkan nilai selisih jarak rata-rata $0,5 \mathrm{~m}$ antara Google maps dan Perhitungan Ecluidian.

\subsubsection{Pengujian Sensor BMP 180}

Pengujian Sensor BMP 180 dibandingkan dengan hasil pengukuran sensor barometer yang terdapat pada iphone 6S. adapaun hasil pengujian nilai ketinggian dan tekanran udara dapat dilihat pada tabel berikut

Tabel 2 Pengujian Ketinggian BMP 180

\begin{tabular}{|c|c|c|c|}
\hline Waktu & $\begin{array}{c}\text { Nilai } \\
\text { ketinggian } \\
\text { (BMP 180) }\end{array}$ & $\begin{array}{c}\text { Nilai } \\
\text { Ketinggian } \\
\text { (Iphone 6S) }\end{array}$ & Error (\%) \\
\hline $19: 24$ & $484,36 \mathrm{~m}$ & $493 \mathrm{~m}$ & 1,75 \\
\hline $19: 23$ & $484,71 \mathrm{~m}$ & $493 \mathrm{~m}$ & 1,68 \\
\hline $19: 22$ & $484,27 \mathrm{~m}$ & $493 \mathrm{~m}$ & 1,77 \\
\hline $19: 21$ & $484,71 \mathrm{~m}$ & $493 \mathrm{~m}$ & 1,68 \\
\hline $19: 20$ & $484,27 \mathrm{~m}$ & $493 \mathrm{~m}$ & 1,77 \\
\hline $19: 15$ & $484,45 \mathrm{~m}$ & $493 \mathrm{~m}$ & 1,73 \\
\hline \multicolumn{4}{|c|}{ Rata - Rata Error } \\
\hline
\end{tabular}


Tabel 3 Pengujian Tekanan

\begin{tabular}{|c|c|c|c|}
\hline Waktu & $\begin{array}{c}\text { Nilai } \\
\text { Tekanan } \\
\text { (BMP 180) }\end{array}$ & $\begin{array}{c}\text { Nilai } \\
\text { Tekanan } \\
\text { (Iphone 6S) }\end{array}$ & Error (\%) \\
\hline $19: 24$ & $959,23 \mathrm{mb}$ & $1010,0 \mathrm{mb}$ & 5,02 \\
\hline $19: 23$ & $959,22 \mathrm{mb}$ & $1007.5 \mathrm{mb}$ & 4,79 \\
\hline $19: 22$ & $959,24 \mathrm{mb}$ & $1007.0 \mathrm{mb}$ & 4,74 \\
\hline $19: 21$ & $959,16 \mathrm{mb}$ & $1007.0 \mathrm{mb}$ & 4,75 \\
\hline $19: 20$ & $959,17 \mathrm{mb}$ & $1007.0 \mathrm{mb}$ & 4,74 \\
\hline $19: 15$ & $959,28 \mathrm{mb}$ & $1007.0 \mathrm{mb}$ & 4,73 \\
\hline \multicolumn{4}{|c|}{ Rata-Rata } \\
\hline
\end{tabular}

Pada 6 kali percobaan sensor BMP 180 menghasilkan nilai rata-rata error $1,73 \%$ pada pengukuran ketinggian dan rata-rata error $4,79 \%$ pada pengukuran tekanan udara.

\subsubsection{Pengujian Sensor DHT 11}

Pengujian Sensor DHT 11 dilakukan dengan membandingkan nilai ukur dari sensor dan alat ukur yang sudah ada yaitu hygrometer. Berikut hasil pengujian dari sensor DHT 11

Tabel 4 Pengujian Suhu DHT 11

\begin{tabular}{|c|c|c|c|}
\hline Waktu & $\begin{array}{c}\text { Nilai Suhu } \\
\text { (DHT 11) }\end{array}$ & $\begin{array}{c}\text { Nilai Suhu } \\
\text { (higrometer) }\end{array}$ & Error(\%) \\
\hline $19: 24$ & $26^{\circ} \mathrm{C}$ & $25^{\circ} \mathrm{C}$ & 4 \\
\hline $19: 23$ & $26{ }^{\circ} \mathrm{C}$ & $25^{\circ} \mathrm{C}$ & 4 \\
\hline $19: 22$ & $26{ }^{\circ} \mathrm{C}$ & $25^{\circ} \mathrm{C}$ & 4 \\
\hline $19: 21$ & $26{ }^{\circ} \mathrm{C}$ & $25^{\circ} \mathrm{C}$ & 4 \\
\hline $19: 20$ & $26{ }^{\circ} \mathrm{C}$ & $25^{\circ} \mathrm{C}$ & 4 \\
\hline $19: 16$ & $27{ }^{\circ} \mathrm{C}$ & $25^{\circ} \mathrm{C}$ & 8 \\
\hline \multicolumn{4}{|c|}{ Rata-Rata Error } \\
\hline
\end{tabular}

Tabel 5 Pengujian Kelembaban DHT 11

\begin{tabular}{|c|c|c|c|}
\hline Waktu & $\begin{array}{c}\text { Nilai } \\
\text { Kelembaban } \\
\text { (DHT 11) }\end{array}$ & $\begin{array}{c}\text { Nilai } \\
\text { Kelembaban } \\
\text { (higrometer) }\end{array}$ & Error(\%) \\
\hline $19: 24$ & $84 \%$ & $87 \%$ & 3,44 \\
\hline $19: 23$ & $84 \%$ & $86 \%$ & 2,32 \\
\hline $19: 22$ & $83 \%$ & $86 \%$ & 3,48 \\
\hline $19: 21$ & $83 \%$ & $86 \%$ & 3,48 \\
\hline $19: 20$ & $82 \%$ & $86 \%$ & 4,65 \\
\hline $19: 16$ & $80 \%$ & $85 \%$ & 5,88 \\
\hline \multicolumn{4}{|c|}{ Rata-Rata Error } \\
\hline
\end{tabular}

Pada 6 kali percobaan sensor DHT 11 menghasilkan nilai rata-rata error $4,66 \%$ pada pengukuran suhu dan ratarata error $3,87 \%$ pada pengukuran kelembaban udara.

\subsubsection{Pengujian Sensor Hujan}

Pengujian sensor Hujan ini dilakukan untuk mengetahui apakah sensor ini mampu mendeteksi adanya hujan dengan baik atau tidak. Pengujian dilakukan dengan cara meneteskan beberapa titik air ke bagian panel dari sensor hujan sedikit demi sedikit. Berikut hasil pengujian dari sensor hujan

Tabel 6 Pengujian sensor hujan

\begin{tabular}{|c|c|c|}
\hline Percobaan & $\begin{array}{c}\text { Nilai } \\
\text { Analog }\end{array}$ & Keterangan \\
\hline Tidak Ditetesi Air & 1015 & Tidak Hujan \\
\hline Diberi 1 Tetes Air & 561 & Hujan \\
\hline Diberi 2 Tetes Air & 449 & Hujan \\
\hline Diberi 3 Tetes Air & 435 & Hujan \\
\hline Diberi 4 Tetes Air & 368 & Hujan \\
\hline Diberi 5 Tetes Air & 359 & Hujan \\
\hline
\end{tabular}

Dari pengujian di atas didapatkan nilai analog sensor apabila panel kering 1015, kemudian jika ditetesi air maka nilai analaog sensor akan semakin berkurang.

\subsubsection{Pengujian Modul ESP 8266}

Pengujian Modul ESP8266-01 dilakukan untuk mengetahui seberapa cepat waktu pengiriman data dari arduino uno ke database/website. Pengujian dilakukan dengan cara mencatat waktu awal pengiriman dan waktu data terkirim atau tersimpan pada database. Adapun hasil pengujianya dapat dilihat pada tabel di bawah

Tabel 7 Pengujian Modul ESP 8266

\begin{tabular}{|c|c|c|}
\hline $\begin{array}{c}\text { Waktu } \\
\text { Pengiriman }\end{array}$ & $\begin{array}{c}\text { Waktu } \\
\text { Penerimaan }\end{array}$ & $\begin{array}{c}\text { Keterangan } \\
\text { Pengiriman Data }\end{array}$ \\
\hline $20: 19: 01$ & $20: 19: 04$ & Terkirim \\
\hline $20: 19: 19$ & $20: 19: 23$ & Terkirim \\
\hline $20: 19: 38$ & - & Error \\
\hline $20: 20: 20$ & $20: 20: 23$ & Terkirim \\
\hline $20: 20: 38$ & $20: 20: 41$ & Terkirim \\
\hline $20: 21: 33$ & $20: 21: 36$ & Terkirim \\
\hline
\end{tabular}

Pada 6 kali percobaan modul ESP 8266 pengiriman data didapatkan 5 data terkirim dan $1 \mathrm{kali}$ pengiriman error atau gagal. Untuk interval waktu pengirimanya sendiri antara 3 sampai 4 second.

\subsubsection{Pengujian Sensor Anemometer}

Pengujian sensor anemometer dilakuan dengan cara membandingkan dengan alat anemometer yang sudah ada. Ditempatkan pada tempat yang sama kemudian dibandingkan nilainya. Berikut ini hasil pengujian dari sensor anemometer.

Tabel 8 Pengujian Sensor Anemometer

\begin{tabular}{|c|c|c|c|}
\hline Waktu & $\begin{array}{c}\text { Kec. Angin } \\
\text { (Sensor } \\
\text { Anemometer) }\end{array}$ & $\begin{array}{c}\text { Kec. Angin } \\
\text { (Alat } \\
\text { Anemometer) }\end{array}$ & $\begin{array}{c}\text { Error } \\
(\%)\end{array}$ \\
\hline 07.43 & $3.83 \mathrm{~m} / \mathrm{s}$ & $2 \mathrm{~m} / \mathrm{s}$ & 61,5 \\
\hline 07.45 & $1,56 \mathrm{~m} / \mathrm{s}$ & $0,9 \mathrm{~m} / \mathrm{s}$ & 100 \\
\hline 07.46 & $2,41 \mathrm{~m} / \mathrm{s}$ & $1,2 \mathrm{~m} / \mathrm{s}$ & 85.83 \\
\hline 07.50 & $2,92 \mathrm{~m} / \mathrm{s}$ & $1,5 \mathrm{~m} / \mathrm{s}$ & 38,66 \\
\hline 07.52 & $3,03 \mathrm{~m} / \mathrm{s}$ & $1,6 \mathrm{~m} / \mathrm{s}$ & 74,37 \\
\hline 07.53 & $6,77 \mathrm{~m} / \mathrm{s}$ & $2,5 \mathrm{~m} / \mathrm{s}$ & 66,8 \\
\hline \multicolumn{4}{|c|}{ Rata-rata } \\
\hline
\end{tabular}


Pengujian diatas dilakukan dengan cara membandingkan sensor anemometer dengan alat anemometer yang sudah ada. Dari 6 kali percobaan diatas didapatkan hasil rata-rata nilai error sebesar $71,19 \%$

\subsection{Pengujian Hasil Data Prototype}

Pengujian ini dilakukan dengan cara membandingkan hasil data yang di tangkap sensor dengan data cuaca perjam dari BMKG dan Accuweather (aplikasi cuaca pada smartphone) pada pukul 7 pagi.

Tabel 9 Pengujian dengan data BMKG

\begin{tabular}{|l|c|c|c|}
\hline Parameter & $\begin{array}{c}\text { Prototype } \\
\text { alat }\end{array}$ & BMKG & $\begin{array}{c}\text { Error } \\
(\%)\end{array}$ \\
\hline Suhu & $27{ }^{\circ} \mathrm{C}$ & $19{ }^{\circ} \mathrm{C}$ & 42,10 \\
\hline Kelembaban & $80 \%$ & $80 \%$ & 0 \\
\hline Kec. Angin & $0,14 \mathrm{~m} / \mathrm{s}$ & $5,55 \mathrm{~m} / \mathrm{s}$ & 97,47 \\
\hline $\begin{array}{l}\text { Tekanan } \\
\text { udara }\end{array}$ & $955,24 \mathrm{mbar}$ & - & - \\
\hline Hujan & Tidak Hujan & $\begin{array}{c}\text { Tidak } \\
\text { Hujan }\end{array}$ & 0 \\
\hline
\end{tabular}

Tabel 10 Pengujian dengan data accuweather

\begin{tabular}{|l|c|c|c|}
\hline \multicolumn{1}{|c|}{ Parameter } & $\begin{array}{c}\text { Prototype } \\
\text { alat }\end{array}$ & Accuweather & $\begin{array}{c}\text { Error } \\
(\%)\end{array}$ \\
\hline Suhu & $27^{\circ} \mathrm{C}$ & $23^{\circ} \mathrm{C}$ & 17,39 \\
\hline Kelembaban & $80 \%$ & $73 \%$ & 8,75 \\
\hline Kec. Angin & $0,14 \mathrm{~m} / \mathrm{s}$ & $1,1 \mathrm{~m} / \mathrm{s}$ & 87,27 \\
\hline $\begin{array}{l}\text { Tekanan } \\
\text { udara }\end{array}$ & $\begin{array}{c}955,24 \\
\text { mbar }\end{array}$ & $1008,6 \mathrm{mbar}$ & 5,29 \\
\hline Hujan & $\begin{array}{c}\text { Tidak } \\
\text { Hujan }\end{array}$ & Tidak Hujan & 0 \\
\hline
\end{tabular}

Dari pengujian diatas didapatkan nilai error yang paling tinggi adalah kecepatan angin dengan nilai error $97,47 \%$ untuk perbandingan dengan BMKG dan $87,27 \%$ untuk perbandingan dengan accuweather.

\subsection{Pembahasan dan Pengujian Website}

\subsubsection{Halaman Home / Dashboard}

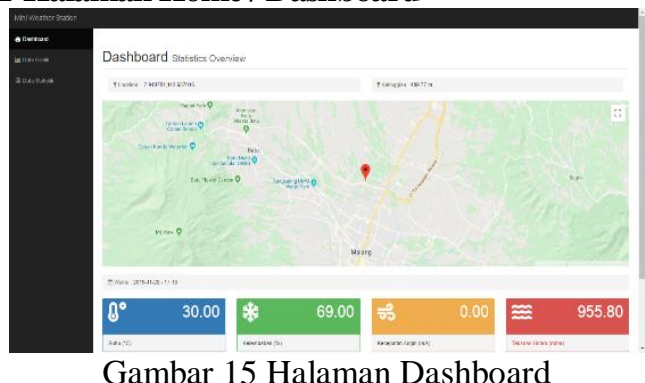

Halaman dashboard berfungsi sebagai halaman utama web. Pada halaman ini website mampu menampilkan nilai cuaca secara real time dalam interval waktu tertentu, kemudian tampilan lokasi dimana pengukuan cuaca dilakukan dalam bentuk koordinat dan peta yang di beri marker atau penanda. Yang ditampilkan pada halaman dashboard ini meliputi, lokasi, ketinggian, suhu, kelembaban udara, kecepatan angin, tekanan udara, dan deteksi hujan.

\subsubsection{Halaman Data Grafik}

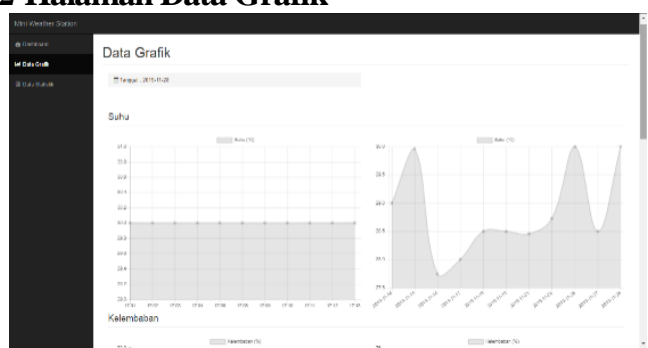

Gambar 16 Halaman Data Grafik

Halaman grafik berfungsi menampilkan data pengukuran cuaca dalam bentuk grafik dalam interval waktu per menit dan rata-rata per tanggal. Untuk grafik yang ditampilkan yaitu suhu, kelembaban udara, tekanan udara, dan kecepatan angina secara terpisah-pisah.

\subsubsection{Halaman Data Statistik}

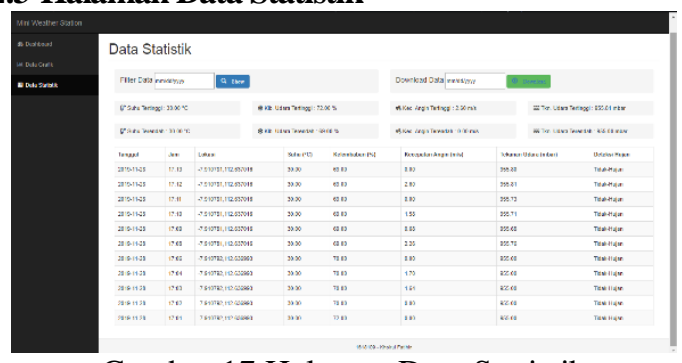

Gambar 17 Halaman Data Statistik

Halaman data statistic berfungsi menampilkan semua data yang di tangkap oleh pengukur cuaca dan di tampilkan dalam bentuk tabel per tanggal. Pada halaman ini juga terdapat tampilan pengukuran cuaca tertinggi dan terendah. User dapat mem-filter untuk menampilkan data sesuai tanggal yang di inginkan. User juga bisa men-download data sesuai tanggal yang dipilih oleh user.

\subsubsection{Pengujian website}

Tabel 11 Hasil Pengujian Website

\begin{tabular}{|l|l|l|c|}
\hline No & Pengujian & \multicolumn{1}{|c|}{ Keterangan } & Hasil \\
\hline 1 & Dashboard & $\begin{array}{l}\text { User dapat mengetahui } \\
\text { nilai cuaca terakhir dari } \\
\text { data yang masuk pada } \\
\text { database }\end{array}$ & $\checkmark$ \\
\hline 2 & Pin lokasi & $\begin{array}{l}\text { Dapat menandai lokasi } \\
\text { terakhir dari data yang } \\
\text { masuk pada database }\end{array}$ & $\checkmark$ \\
\hline 3 & $\begin{array}{l}\text { Geocoding } \\
\text { Merubah koordinat } \\
\text { latitude dan longitude } \\
\text { menjadi sebuah alamat }\end{array}$ & $\mathrm{X}$ \\
\hline 4 & Lokasi Alat & $\begin{array}{l}\text { Menampilkan lokasi } \\
\text { pengukur cuaca berupa }\end{array}$ & $\checkmark$ \\
\hline
\end{tabular}




\begin{tabular}{|l|l|l|c|}
\hline No & Pengujian & \multicolumn{1}{|c|}{ Keterangan } & Hasil \\
\hline 5 & Data Grafik & $\begin{array}{l}\text { User dapat mengetahui } \\
\text { nilai sensor dalam bentuk } \\
\text { grafik per tanggal dan per } \\
\text { menit }\end{array}$ & $\checkmark$ \\
\hline 6 & Data Statistik & $\begin{array}{l}\text { User dapat mengetahui } \\
\text { nilai sensor dalam bentuk } \\
\text { tabel per tanggal. }\end{array}$ & $\checkmark$ \\
\hline 7 & $\begin{array}{l}\text { Filter Data } \\
\text { (Button) }\end{array}$ & $\begin{array}{l}\text { Menampilkan Data Tabel } \\
\text { dengan tanggal yang } \\
\text { ditentukan oleh user }\end{array}$ & $\checkmark$ \\
\hline 8 & $\begin{array}{l}\text { Download } \\
\text { Data (Button) }\end{array}$ & $\begin{array}{l}\text { Download Data cuaca } \\
\text { berdasarkan tanngal yang } \\
\text { dipilih user }\end{array}$ & $\checkmark$ \\
\hline
\end{tabular}

Keterangan :

$\checkmark \quad$ : Berhasil

$\mathrm{X}$ : Gagal

Dari pengujian semua aspek website hanya satu yang tidak berhasil atau gagal yaitu geocoding lokasi

\section{KESIMPULAN DAN SARAN}

\subsection{Kesimpulan}

Berdasarkan hasil analisa dan pengujian yang telah dilakukan, maka dapat diambil beberapa kesimpulan sebagai berikut:

1. Hasil pengujian Modul GPS dengan smartphone menggunakan tracking google map dan perhitungan Euclidian menghasilkan rata-rata selisih jarak $0,5 \mathrm{~m}$

2. Hasil pengukuran dari sensor BMP 180 dibandingkan dengan sensor barometer yang terdapat pada iphone $6 \mathrm{~s}$ menghasilkan nilai rata-rata error $1,73 \%$ pada pengukuran ketinggian dan rata-rata error $4,79 \%$ pada pengukuran tekanan udara.

3. Hasil pengukuran dari sensor DHT 11 dibandingkan dengan alat ukur higrometer menghasilkan nilai rata-rata error $4,66 \%$ pada pengukuran suhu dan rata-rata error $3,87 \%$ pada pengukuran kelembaban udara

4. Dari hasil pengujian sensor hujan dengan cara memberikan beberapa titik-titik air pada panel sensor didapatkan nilai analog sensor apabila panel kering 1015, kemudian jika ditetesi air maka nilai analaog sensor akan semakin berkurang.

5. Pengujian ESP8266-01 dilakukan dengan mengirimkan data dari arduino ke database sebanyak 6 kali, dan dari 6 kali percobaan tersebut
5 kali data terkirim dan 1 data error atau tidak terkirim.

6. Dari 6 kali pengujian sensor anemometer dengan alat anemometer yang sudah ada didapatkan hasil rata-rata nilai error sebesar $71,19 \%$

7. Dari pengujian data yang dihasilkan alat prototype dengan data BMKG dan accuweather pada pukul 7 pagi didapatkan nilai error yang paling tinggi adalah kecepatan angin dengan nilai error 97,47\% untuk perbandingan dengan BMKG dan 87,27\% untuk perbandingan dengan accuweather.

8. Dari beberapa kali percobaan sistem bekerja dengan baik, alat mampu menangkap dan mengirim data sensor untuk ditampilkan pada website dengan baik, meskipun memiliki nilai error dikarenakan harganya yang relative murah.

\subsection{Saran}

Adapun saran yang diberikan untuk penelitian selanjutnya antara lain:

1. Penambahan sensor untuk memperbanyak parameter pengukuran cuaca seperti sensor cahaya dan curah hujan

2. Penambahan geocoding lokasi untuk untuk memperjelas alamat yang dihasilkan oleh sensor GPS

3. Agar lebih sempurna bisa ditambahkan sistem prediksi cuaca menggunakan data logger yang telah tersimpan

\section{DAFTAR PUSTAKA}

[1] Republik Indonesia. Undang-Undang tentang Meteorologi, Klimatologi, dan Geofisika. 2009, Jakarta: Sekretariat Negara, 2009.

[2] Salindri, Z. H., Darjat, D., \& Riyadi, M. A. (2016). Rancang Bangun Mini weather Station Menggunakan WEB Berbasis Arduino ATMEGA 2560. TRANSIENT, 4(4), 1079-1086., and Vocational Education), 1(1), pp.37-43.

[3] Thoyibi, M. M., Sanjaya, K. T., \& Amaluddin, F. (2018). RANCANG BANGUN MINI WEATHER STATION BERBASIS SMS GATEWAY MENGGUNAKAN ARDUINO UNO. Prosiding SNasPPM, 3(1), 367-370.

[4] Irawan, J. D., Prasetio, S., \& Adi, S. (2016). Pengembangan Kunci Elektronik Menggunakan RFID Dengan Sistem IoT. Industri Inovatif: Jurnal Teknik Industri, 6(2), 28-32.

[5] Fitriani R. (2019). WEATHER MEASURING PROTOTYPE USING ARDUINO. Jurnal Sains dan Teknologi Mitigasi Bencana, Vol. 14, No. 1. 